\title{
Fra lærerstyrt undervisning til varierte læringsformer
}

\author{
A. N. Jakobsen og L. Waldenstrøm, \\ Institutt for bioteknologi og matvitenskap, Norges Teknisk-naturvitenskaplige universitet (NTNU)
}

\begin{abstract}
Motivasjon er en av de viktigste faktorene for laring. Aktive og varierte læringsformer, samt bruk av formative og hyppige tilbakemeldinger er sentrale ingredienser for å skape motivasjon for læring. Dette var bakgrunnen for at emnet produktutvikling ved bachelorstudiet i matteknologi ved NTNU høsten 2015 ble lagt om fra å være et lærerstyrt teoretisk emne til å bli et emne som bruker aktiviserende og varierte laringsformer i kombinasjon med hyppige tilbakemeldinger fra lærere og medstudenter. Omleggingen var også basert på studentenes forventninger om en praktisk tilnærming til et emne i produktutvikling. Emnet fikk tittelen «Produktutvikling og sensorisk analyse - brygging av håndverksøl». Målet var å oppnå mer motiverte og engasjerte studenter, samt å forbedre studentenes akademiske prestasjoner. Undervisningsopplegget har elementer fra ulike didaktiske konsept; både problembasert læring, casemetoden, prosjektarbeid, forelesninger og arbeidslivsmedvirkning. Studentene har flere muntlige presentasjoner underveis i prosessen. Ølbrygging ble valgt som case fordi bryggeprosessen er tverrfaglig og krever at studentene bruker kunnskap ervervet $i$ flere andre emner. Ølbrygging er en aktivitet som har oppnådd stor allmenninteresse de siste årene og kan av den grunn virke ekstra motiverende. Emneevalueringer basert på referansegruppemetodikk viste at studentene synes emnet ble engasjerende og at det praktiske arbeidet var appellerende og lærerikt. De hyppige direkte tilbakemeldingene ble trukket frem som positive. Mange av studentene rapporterte negative opplevelser knyttet til de muntlige fremføringene på forhånd, men endret mening etter gjennomføring. Læringsutbytte i emnet ble i gjennomsnitt skalert til 4,1 av maksimalt 5. De akademiske prestasjonene for de to kullene som har gjennomført emnet med studentaktivt undervisningsopplegg var signifikant bedre enn for de to forhenværende kullene. Erfaringene tyder på at studentene bør lære mer om gruppearbeid og hvordan konflikter i grupper skal håndteres. Lærerne opplevde at studentene viste eierskap til problemstillingen og at de viste høyt engasjement. Bruk av varierte og aktive læringsformer er motiverende, men også ressurskrevende for læreren.
\end{abstract}

Nøkkelord: varierte læringsformer, hyppige tilbakemeldinger, motivasjon, produktutvikling

\section{INNLEDNING}

Kvalitetsreformen (ST.meld. nr. 27, 2000-2001) i høyere utdanning ble lansert i 2003 med et ønske om å bedre undervisningskvaliteten i sektoren. Reformen uttrykte et behov for å bevege seg i retning av et mer konstruktivistisk og sosiokulturelt læringssyn med fokus på studentaktive læringsformer og behov for et læringsfellesskap. Utdanningsinstitusjonene ble bedt om å følge opp studentene tettere gjennom bedre veiledning og bruk av formative evalueringsmetoder på bekostning av tradisjonelle skriftlige eksamener. Betydningen av hyppige tilbakemeldinger og fokus på individuell oppfølging ble vektlagt. Ønske om en mer aktiv studentrolle støttes av pedagogisk forskning (Cazan, 2007) og mange studier viser at systematiske og gode tilbakemeldinger er viktig for at studentene skal opprettholde motivasjon, fremdrift og forbedring i sitt arbeid (Cazan, 2007; Hattie og Timperley 2007).

Freeman m. fl. (2014) definerer aktiv læring på følgende måte: “Active learning engages students in the process of learning through activities and/or discussion in class, as opposed to passively listening to an expert. It emphasizes higher-order thinking and often involves group work". Fraser m.fl. (2014) vektlegger at aktiv læring må engasjere hver enkelt student og påpeker at mange former for aktiv læring som benyttes kun aktiverer en liten andel av studentene og dermed egentlig er passiv læring fordekt som aktiv læring. Fordekt aktiv læring kan eksempelvis gjøres gjennom demonstrasjoner, bruk av klasseroms-responssystemer og klasseromsdiskusjoner hvor kun enkelte studenter deltar. Fraser m.fl. (2014) definerer aktiv læring på følgende måte: «interactive engagement methods promote conceptual understanding through interactive engagement of students in heads-on (always) and hands-on (usually) 
activities which yield immediate individual feedback to all students through discussion with peers and/or instructors".

Caseundervisning, problembasert læring og prosjektarbeid er erfaringsbasert læring og tuftet på en ide om at kunnskap ikke er uforanderlig, men formes og omformes gjennom erfaring. Arbeidsmetodene krever kreativ og kritisk tenking gjennom refleksjon og bearbeiding av erfaringer som bidrar til å bedre kvalifisere studenten til arbeidslivet. (Strømsø m.fl., 2006). Problembasert læring gjennomføres normalt i basisgrupper med en lærer som veileder, mens casarbeidet normalt er en seminarform med lærer seminarleder (Pettersen, 2005). Gjennom prosjektarbeid kan studentene individuelt eller i gruppe utrede en problemstilling og det forventes et konkret resultat i form av eksempelvis en rapport eller presentasjon (Strømsø m.fl., 2006).

I en studie av studiekvalitet ved amerikanske universiteter sammenfattet Chickering and Gamson (1987) sju generelle prinsipper for god undervisningspraksis. Ett av prinsippene er «Good practice in undergraduate education gives prompt feedback». Rask tilbakemelding trekkes altså fram som viktig for god undervisning. Hattie og Timperley (2007) fremhever at tilbakemeldinger er en av de faktorene som i sterkest grad påvirker læring, og type tilbakemelding og hvordan den blir gitt er avgjørende. Effektive tilbakemeldinger må besvare tre viktige spørsmål: Hva er målet? Hvordan er progresjonen? Og hvilke aktiviteter må iverksettes? Dersom studentene må benytte tilbakemeldingene de får vil det gi størst læringseffekt. Det er mange måter tilbakemeldinger kan gis på og tilbakemelding fra medstudenter kan ha kvaliteter som det er vanskelig å få frem ved tilbakemeldinger fra lærer. Eksempelvis hvis to studentgrupper skal løse en identisk oppgave, vil det å få innsikt i hvordan medstudenter løser samme problem ved å vurdere hverandres løsning gi en helt annen øvelse i kritisk tenking enn om tilbakemeldingen kommer fra en lærer (Topping K, 1998, omtalt i Haugan og Lysebo, 2015). Evaluering av kvalitetsreformen har påpekt at norske universitet og høgskoler fortsatt bruker avsluttende eksamener som den viktigste evalueringskilden av studenter (Michelsen og Aamodt, 2007). Videre viser NOKUTs analyser av Studiebarometeret for perioden 2013-2015 at studentene er mindre fornøyde med tilbakemelding og oppfølging fra faglig ansatte enn nesten alle de andre spørsmålene de svarer på (Hamberg m.fl., 2016).

Motivasjon er antagelig den viktigste faktoren en lærer kan spille på for å fremme studentenes læring (Williams og Williams, 2011; Shulman 2002; Biggs og Tang, 2007). Motivasjon er på mange måter de faktorene som bidrar til aktiviteter hos studentene og holder læringsprosessen i gang. Avgjørende for motivasjon er at studentene finner læringsaktivitetene viktige og verdifulle og at de oppnår suksess hvis de engasjerer seg i oppgavene (Biggs og Tang, 2007). Basert på studier av Williams og Williams (2011) påvirkes studentenes motivasjon av fem sentrale faktorer: studenten selv, laereren, innhold, metode/prosess og laeringsmiljøet.

Studenten på universitetsnivå kan være ytre motivert, sosialt motivert, prestasjonsmotivert og/eller indre motivert. Mange vil hevde at den indre motivasjonen for læring er den sterkeste formen for motivasjon og som vil bidra til dybdelæring, men Biggs og Tang (2007) påpeker at for å skape et engasjement blant studentene er det å aktivere alle formene for motivasjon. Studentenes indre motivasjon påvirkes av tanker og følelser, og negative tankemønstre vil vanskeliggjøre læring (Williams og Williams, 2011). Lareren har en sentral rolle for å legge til rette for læring gjennom å være en tydelig faglig leder i klasserommet og uttrykke tydelige mål. Læreren rolle har skiftet fra å være en kunnskapsdispenser til å være tilrettelegger for læring (Williams og Williams, 2011). Innhold og emnedesign kan bidrar til å øke studentenes motivasjon. Studenten bør oppleve mestring, tilhørighet, valgfrihet, eierskap til arbeidet, relevans, variasjon, kreativ og kritisk tenking, samt oppleve av innholdet har en nyhetsverdi. (Williams og Williams, 2011). Emneinnhold som har stor grad av nyhetsverdi, eksempelvis ved introduksjon av noe uventet eller uvanlig, kan skape en kognitiv konflikt hos studenten som kan bidra til økt motivasjon. Økt nyhetsverdi kan eksempelvis oppnås via uvante undervisningsformer som spill, uventede demonstrasjoner eller bruk av fantasi (Palmer, 2007; Williams og Williams, 2011). Metoden eller prosessen må være kreativ, oppmuntrende, interessant og oppleves som fordelaktig for studenten. Guidede diskusjoner eller bruk av case fremheves som viktige verktøy (Williams og Williams, 2011). For å sikre studentmotivasjon må lceringsmiljøet være tilgjengelig, trygt og positivt, det må være lagt til rette for åpenhet og mulighet til å lære av hverandres feil, det må tilrettelegges for gruppearbeid samtidig som hvert enkelt individ ivaretas. Williams og Williams (2011) vektlegger at studentene bør utsettes for 
variasjon av læringsmetodikk for å øke motivasjon til studiene. Oppsummert handler motivasjon om kvaliteten på relasjonen mellom studenten, læringssituasjonen og læringsoppgaven tilrettelagt og ledet av læreren.

I denne artikkelen presenterer vi utvikling og implementering av et produktutviklingsemne med variert bruk av studentaktive læringsformer kombinert med hyppige tilbakemeldinger. Erfaringer med emnet blir diskutert.

Vi ønsket svar på to spørsmål:

1. Kan studentaktive læringsformer kombinert med hyppige tilbakemeldinger fra veiledere og medstudenter bidra til mer motiverte studenter i produktutvikling på bachelornivå?

2. Kan bruk av studentaktive læringsformer kombinert med hyppige tilbakemeldinger bidra til bedre akademiske prestasjoner enn tradisjonelle forelesninger i produktutvikling på bachelornivå?

\section{BAKGRUNN FOR OMLEGGING AV EMNET}

Innen bachelorutdanning i matteknologi ved NTNU er det de siste årene forsøkt å øke omfanget av studentaktive læringsformer. Et eksempel på dette er innføring av et epidemiologisk spill i etterforskning av matbårne utbrudd i emnet mattrygghet og kvalitetsstyring. Det samme emnet benytter også omvendt hospitering, hvor en representant fra Mattilsynet gjennomfører deler av undervisningen ved å diskutere reelle case fra matbårne utbrudd (Karlsen m.fl., 2015).

Inntil høsten 2015 var emnet produktutvikling designet på nokså tradisjonelt vis. Emnet bestod av timeplanlagte forelesninger og en semesteroppgave. Sluttvurderingen var basert på semesteroppgaven og en skriftlig eksamen. Lærerne observerte relativt lite engasjement for noe som burde være spennende og relevant. Emneevalueringen av undervisningen i emnet høsten 2014 (Emnerapport, AFT, 2014) avdekket at studentene ønsket mindre bruk av tradisjonelle forelesninger med PowerPointpresentasjoner og økt bruk av en studentaktiv og praktisk tilnærming til produktutvikling. Emneevalueringen ble gjennomført av studenttillitsvalgt som innhentet informasjon $i$ en spørreundersøkelse som $91 \%$ av emnets studenter besvarte. Resultatene og tiltak for å bedre undervisningskvaliteten $\mathrm{i}$ emnet ble diskuterte gjennom to møter mellom studenttillitsvalgt, emneansvarlig og studieleder. Emneevalueringen avdekket videre lav egeninnsats av studentene i emnet og de som ikke deltok i undervisningen oppga som grunn at de synes de kunne lese presentasjonene selv da de var tilgjengelig elektronisk på læringsplattformen.

Motivasjonen for å legge om undervisningen var altså forankret i både studentenes forventning om en mer studentaktiv rolle og lærernes ønske om mer selvregulerte og motiverte studenter. Lærerne ønsket større studentengasjementet i undervisningsrommet og ville samtidig trene studentene $\mathrm{i}$ å presentere og diskutere faglige problemstillinger. Forskning tyder på at studentene kan læres til å bli mer selvregulert (Zimmerman, 2002).

\section{BESKRIVELSE AV UNDERVISNINGSOPPLEGG}

Emnet introduseres med to intensive dager bestående av forelesninger, film om relevant teori, gjesteforelesninger fra industrien og sensoriske vurdering av øl. Etter oppstartsdagene velger studentene grupper og produktutviklingsoppgave med øl som case. Gruppene skal i løpet av en ukes tid presenterer minimum to konkrete løsninger på casen muntlig for medstudenter og lærere. For å komme med løsninger må de selvstendig tilegne seg en del teori. Diskusjon rundt løsningene foregår i plenum rett etter hver enkelt presentasjon. To og to grupper har samme case. Dette gir gruppene innsikt i hvordan medstudenter tenker rundt samme problemstilling, det gir trening i kritisk tenking og øker sannsynligvis motivasjonen til å bidra i diskusjonen.

Basert på tilbakemeldingene i plenum og veiledningssamtale med lærer, samt besøk hos lokale bryggerier og andre fagpersoner, utarbeider gruppen en endelig løsning på casen. Deretter gjennomfører de en praktisk selvstendig ølbrygging og en sensorisk analyse av ferdig produkt for å kontrollere måloppnåelse. Kunnskap om sensoriske analyser har studentene fra tidligere, men her må den 
kunnskapen anvendes på en ny måte. Endelige resultater og en selvevaluering av prosjektet presenteres igjen muntlig med direkte tilbakemeldinger fra lærere og medstudenter før alt samles $\mathrm{i}$ en semesteroppgave som er endelig vurderingsform. Dette gir gruppene mulighet til å benytte tilbakemeldingene direkte i oppgaveskrivingen.

\section{DATAINNSAMLING}

Resultatene som presenteres er basert på data fra tre ulike kilder: Den første kilden er data fra møtene med referansegruppene $i$ emnet med nytt emnedesign, gjennomført 2015 og 2016. Referansegruppemetodikk (NTNU u.å.; Pettersen, 2005) er basert på uformelle møter (minimum tre) mellom emneansvarlig og en gruppe av utvalgte studenter gjennom semesteret slik at læreren får kontinuerlig tilbakemelding på undervisningen. Referansegruppa er representanter fra studentene og skal formidle synspunkter fra hele studentgruppa. Det er referansegruppas ansvar å aktivt innhente synspunkter fra de andre studentene som formidles muntlig til emneansvarlig. Referansegruppa utformer en referansegrupperapport som er offentlig tilgjengelig etter semesterslutt der blant annet forslag til forbedringer skal med. (NTNU u.å.)

Den andre kilden er et spørreskjema om motivasjon som ble utarbeidet og sendt elektronisk, ved bruk av programvaren EyeQuestion ${ }^{\circledR}$, til alle studenter som tok emnet i 2016. Spørreskjemaet ble sendt ut umiddelbart etter at emnet var ferdig og svarprosenten på undersøkelsen var $50 \%$. Programvaren er utviklet for å designe, samle inn og behandle data fra sensoriske tester og forbrukerundersøkelser noe som var med på å påvirke designet. Vi tok utgangspunkt i en Check-All-That-Apply test (CATA) (Meyners \& Castura, 2014). Svaralternativene ble presentert i randomisert rekkefølge (Gastón Ares \& Jaeger, 2013). Studentene ble bedt om å krysse av minimum 3, maksimum 4 alternativer. I tillegg ble studentene bedt om å vurdere eget læringsutbytte i emnet med Likert skala fra 1 (jeg lærte ingenting) til 5 (jeg lærte svært mye). For å sikre anonymitet i undersøkelsen ble det ikke spurt om demografiske opplysninger som alder og kjønn.

Den tredje kilden er karaktereroppnåelse i emnet før (kull 2013 og 2014; totalt 54 studenter) og etter (kull 2015-2016; totalt 72 studenter) omlegging av undervisningen. For å ta høyde for variasjoner i akademiske prestasjoner mellom studentkull, ble karakterene de samme studentene oppnådde i emne mikrobiologi benyttet som sammenligningsgrunnlag. Begge emnene er obligatoriske for studentene. Mikrobiologi ble benyttet som sammenligningsgrunnlag siden alle kullene hadde dette emnet og undervisningsmetodikken i mikrobiologi ble ikke vesentlig endret i perioden. Mikrobiologi undervises med tradisjonelle forelesninger. For å kunne sammenligne eksamensresultater mellom emner og kull, ble eksamenskarakterene konvertert til tall på følgende måte: $\mathrm{A}=6, \mathrm{~B}=5, \mathrm{C}=4, \mathrm{D}=3, \mathrm{E}=2$ og $\mathrm{F}=1$. En tosidig uparet t-test med antatt ulik varians ( $\mathrm{n}>30$; Walpole, 2016) ble benyttet for å sammenligne to ulike grupper.

\section{RESULTATER}

\subsection{Tilbakemelding fra referansegrupper}

Tilbakemeldingene fra referansegruppene etter implementering av studentaktivt undervisningsopplegg var generelt positive. Referansegruppene refererte at studentene omtalte emnet som gøy og engasjerende. Det ble rapporter at studentene fant det praktiske arbeidet appellerende. Referansegruppene oppga at læringsutbyttet ble oppfattet som høyt og at de fikk et godt innblikk i hele produktutviklingsprosessen ved å jobbe på denne måten. Flere studenter oppga at de fante det uvant, men lærerikt, med så stor grad av selvstendighet både i det praktiske og det teoretiske arbeidet. Direkte tilbakemeldinger på arbeidet underveis var en faktor som ble trukket frem som spesielt positivt i emnet. Det ble påpekt at bedriftsbesøk er motiverende og bidrar til økt læring. $81 \%$ av studentene møtte opp på ikke-obligatoriske bedriftsbesøk.

I diskusjonene kom det frem at mange studenter hadde hatt negative opplevelser knyttet til de muntlige fremføringene på forhånd, men at de fleste oppga det som en positiv og lærerik aktivitet i etterkant. Referansegruppene trakk frem behovet for å lære mer om hvordan gruppearbeid organiseres og spesielt om konflikthåndtering. 


\subsection{Studentmotivasjon}

Studentene ble i en spørreundersøkelse bedt om å kategorisere tanker og følelser de hadde hatt knyttet til det studentaktive emnet gjennom semesteret. Resultatene er gitt i Tabell 1.

Tabell 1. Tanker og følelser som studentene oppgir som mest beskrivende gjennom semesteret i det studentaktive undervisningsopplegget i produktutvikling.

\begin{tabular}{|l|c|}
\hline Tanker og følelser gjennom semesteret & Andel (\%)* \\
\hline Gøy & 36,8 \\
\hline Frustrerende & 36,8 \\
\hline Spennende & 52,6 \\
\hline Skulle ha forberedt oss bedre & 26,0 \\
\hline Interessant & 78,0 \\
\hline Savnet veiledning & 10,5 \\
\hline Utfordrende å måtte sette seg inn i nytt stoff og gjøre alt selv & 47,4 \\
\hline Følelse av selvstendighet & 63,2 \\
\hline Engasjerende & 36,8 \\
\hline Kjedelig & 0,0 \\
\hline
\end{tabular}

*Tallet angir prosentvis antall studenter som har krysset av på det enkelte alternativet. Studentene ble bedt om å krysse av minimum 3, maksimum 4 alternativer. Fritekst med ytterligere kommentarer var mulig.

Tabell 1 viser at de dominerende tankene og følelsene i studentgruppen knyttet til emnet var: interessant (78\%), spennende $(52,6 \%)$ og følelse av selvstendighet $(63,2 \%)$. Ingen studenter krysset av for at emnet var kjedelig.

I den samme undersøkelsen ble studentene bedt om å evaluere sitt eget læringsutbytte i emnet på en skala fra 1 (jeg lærte ingenting) til 5 (jeg lærte svært mye). Gjennomsnittvurderingen av læringsutbyttet var på 4,1 og $73 \%$ av studentene skalerte læringsutbytte som 4 eller 5 . Ingen av studentene ga læringsutbyttet score 1 eller 2.

\subsection{Akademiske prestasjoner}

Effekten av nytt undervisningsopplegg i produktutvikling ble evaluert ved å sammenligne oppnådde eksamenskarakterer i emnet for to kull før (2013-2014) og etter (2015-2016) endringen. Eksamensresultatene de samme studentene oppnådde i mikrobiologi, et emne som undervises semesteret før produktutvikling, ble benyttet for sammenligning. Eksamenskarakterene er gitt i Tabell 2.

Tabell 2: Karaktergjennomsnitt med standardavvik for emnene produktutvikling og mikrobiologi i perioden 2013-2016.

\begin{tabular}{|l|c|c|c|c|}
\hline & $\begin{array}{c}\text { Produktutvikling } \\
\text { Tradisjonelt } \\
2013-2014\end{array}$ & $\begin{array}{c}\text { Produktutvikling } \\
\text { Studentaktivt } \\
2015-2016\end{array}$ & $\begin{array}{c}\text { Mikrobiologi } \\
\text { Tradisjonelt } \\
2013-2014\end{array}$ & $\begin{array}{c}\text { Mikrobiologi } \\
\text { Tradisjonelt } \\
2015-2016\end{array}$ \\
\hline Antall møtt til eksamen & 54 & 72 & 71 & 88 \\
\hline Antall stryk & 2 & 0 & 15 & 12 \\
\hline Gjennomsnittskarakter* & $4,0 \pm 1,0$ & $4,7 \pm 0,8$ & $3,1 \pm 1,5$ & $3,5 \pm 1,4$ \\
\hline p-verdi** & \multicolumn{2}{|c|}{0,0002} & \multicolumn{2}{c|}{0,1} \\
\hline
\end{tabular}

*Gjennomsnitt er regnet av endelig karakterer for kandidatene over to år. Gjennomsnittskarakter ble beregnet ved å konvertere bokstavkarakterene slik: $\mathrm{A}=6, \mathrm{~B}=5, \mathrm{C}=4, \mathrm{D}=3, \mathrm{E}=2$ og $\mathrm{F}=1$.

**Tosidig uparet t-test med antatt ulik varians. Gjennomsnittsverdier regnes som signifikant forskjellig dersom $p$-verdi $\leq 0,05$. 
Tabell 2 viser at de to studentkullene som gjennomførte produktutviklingsemnet etter omlegging av undervisningen (2015-2016) presterte signifikant bedre enn studentkullene fra de to forhenværende årene (2013-2014). Til sammenligning ble det ikke observert en lignende forbedring av karaktergjennomsnitt i emnet mikrobiologi i samme tidsperiode.

\section{DISKUSJON}

Motivasjon og engasjement er en avgjørende faktor for læring (Shulman 2002). For læring på universitetsnivå trekker Biggs og Tang (2007) frem at motivasjonen kan være ytre motivert, sosialt motivert, prestasjonsmotivert og/eller indre motivert. De påpeker videre at for å skape et engasjement blant studentene er det viktig å spille på alle disse faktorene. I det studentaktive emnedesignet for produktutvikling har vi forsøkt å integrere de fire formene for motivasjon. Eksempelvis har vi observert at det går litt konkurranse $\mathrm{i}$ å finne gode og kreative løsninger på casen som skal presenteres for klassen, på å lage det beste ølet og oppnå den beste karakteren. Dette kan handle om å oppnå annerkjennelse, vel så mye av medstudenter som hos lærere, men det kan også handle belønning, iboende trang til å prestere eller indre motivasjon i form av interesse og glede.

For å oppnå motivasjon påpeker Biggs og Tang (2007) at læringsaktiviteter må være viktig og ha verdi for studentene og studentene bør forvente suksess når de engasjerer seg. I produktutviklingsemnet forsøkte vi å legge til rette for dette. Vi observerte eksempelvis stort oppmøte på bedriftsbesøk på kveldstid selv om de ikke var obligatorisk. De ulike studentpresentasjonene i løpet av semesteret ligner caseseminarene som er sentralt i casemetoden (Pettersen, 2005; Strømsø m.fl., 2006). På disse seminarene var to lærere til stede og de ledet diskusjonen etter at gruppene hadde presentert sine problemstillinger. Intensjonen med å ha disse presentasjonene var flere: Skape en kultur for hyppige tilbakemeldinger, trene studentene i faglig kommunikasjon og å lære av hverandre ved se hvordan andre har løst lignende problemstillinger. Erfaringene så langt er at disse formative tilbakemeldingene både fra lærere og medstudenter motiverte gruppene. Det at to og to grupper hadde samme case som skulle diskuteres i plenum gir studentene en unik mulighet til å engasjere seg i diskusjonene siden de har jobbet med samme problemstilling selv. Siden diskusjonene gir tilbakemeldinger som direkte skal brukes videre i arbeidet opplevde studentene det som nyttig og de fikk en følelse av å «gå glipp av» nyttig informasjon dersom de ikke møtte opp. Opplegget ivaretar kvaliteten med medstudentevaluering og viktigheten av at tilbakemeldingene skal komme raskt og være til direkte nytte. Gjennom diskusjonene på ulike nivå (i gruppa, med veileder, med veiledere og resten av klassen) skjer læring og kunnskapstilegnelse i samarbeid med andre i et praksisfellesskap forankret i et sosiokulturelt perspektiv. Målet er at diskusjonene og tilbakemeldingene skal hjelpe den enkelte student til å sette i gang metakognitive prosesser om eget faglig ståsted som gjør dem i stand til å bidra i planleggingen av neste læringsaktivitet.

I undervisningsopplegget er det bevisst kombinert ulike undervisningsformer med et ønske om å skape engasjement. Williams og Williams (2011) vektlegger at studenter bør oppleve et mangfold i læringsmetodikk for å øke motivasjonen. Det er den filosofien vi har lagt til grunn i dette emnedesignet. Vi har ikke målt hvilke av læringsaktivitetene i vårt undervisningsopplegg som bidrar mest til læring eller motivasjon, muligens vil det også variere mellom ulike studenttyper. Kravet til selvstendighet i arbeidet, muntlige diskusjoner og hyppige tilbakemeldinger ble trukket frem av referansegruppene som mest lærerikt. Ølbrygging ble valgt som case fordi prosessen er tverrfaglig og krever at studentene bruker kunnskap ervervet i flere andre emner. Ølbrygging er en samfunnstrend og kan av den grunn virke ekstra motiverende. Lærerne har observert at engasjementet har økt og at flere studenter er aktive. Nyhetsverdien eller introduksjon av noe uventet kan ha bidra til økt motivasjon (Palmer, 2007; Williams og Williams, 2011). Nyhetsverdien og interessen for ølbrygging som tema kan være forbigående. Det er derfor viktig at det kommuniseres at valg av tematikk er faglig fundamentert. Fra litteraturen vet en at læring er kontekstavhengig (Pettersen, 2005), og for å gjøre emnet så yrkesrelevant som mulig var det et ønske om at studentene skulle hente frem igjen kunnskap fra første studieår (spesielt innen sensorisk analyse) og anvende den på en ny måte. Forhåpentligvis bidrar dette til økt prosesseringsdybde og bedre læring slik at studentenes «praksissjokk» blir noe mindre når de kommer ut i jobb. De fleste studieprogram i universitetssektoren har i sine overordnede læringsutbyttebeskrivelser, definert som kunnskap, ferdigheter og generell kompetanse, inkludert at kandidaten skal kunne kommunisere sin fagkunnskap både muntlig og skriftlig. Ved tradisjonelle forelesninger vil de færreste studentene få 
trening i muntlig kommunikasjon. I dette undervisningsopplegget får alle studentene denne treningen gjennom sine presentasjoner og diskusjoner i plenum og i mindre grupper.

Det er kjent at det er noen kognitive flaskehalser knyttet til gruppearbeid. Den mest kjente og best dokumenterte flaskehalsen er det som kalles vagabondering eller social loafing (Pettersen, 2005) som beskriver det faktum at enkelte personer har en tendens til å investere og bruke mindre krefter når de jobber med oppgaver i grupper, sammenlignet med arbeidsinnsatsen de nedlegger når arbeidet er individuelt. Andre individer vil ta på seg for stort ansvar og slik indirekte oppfordrer de andre til å lene seg tilbake. I et forsøk på å motvirke dette fikk studentene velge grupper selv slik at de kunne søke seg mot andre studenter med samme ambisjonsnivå. I emneevalueringen trakk likevel studentene frem behovet for å lære hvordan man jobber i grupper og hvordan konflikter skal håndteres. Gruppearbeidet oppfattes av studentene som både motiverende, engasjerende, forpliktende og frustrerende. Studentene viste stort eierskap til prosjektet. Lærerne opplevde at det økte engasjementet kunne gå på bekostning av andre emner, eksempelvis ved at studentene prioriterte arbeidet med casen fremfor å møte opp på forelesninger i andre emner. For studentenes totale studieutbytte er slike prioriteringer ugunstige. Noen studenter viste frustrasjon over uvant frie rammer og spesielt noen av de teoretisk svakeste studentene, som ble sterkt engasjerte i det innledende arbeidet, ble frustrerte og demotiverte i skriveprosessen for å ferdigstille prosjektoppgaven.

Erfaringene så langt er at selv om det foreleses mindre i emnet enn tidligere så brukes det muligens mer ressurser. Det er arbeidskrevende å utarbeide og vurdere problemstillinger som er egnet, det skal lages avtaler med industrikontrakter for gjesteforelesning og bedriftsbesøk, og det praktiske arbeidet medfører mange spørsmål som studentene trenger veiledning til. Det er krevende for læreren at en aldri vet hvilket spørsmål som kommer. Resultatene fra evalueringen av det studentaktive emnedesignet og de akademiske resultatene indikerer at omleggingen av emnet var vellykket. Både evalueringene innhentet gjennom referansegruppemetodikk og spørreundersøkelser indikerer at studentene fant emnet motiverende og de mente læringsutbyttet var høyt. Referansegruppemetodikk skal være basert på at studentene i gruppa aktivt innhenter informasjon fra sine medstudenter og dermed bringer et representativt syn på undervisningen videre til emneansvarlig. Svakheten ved metoden er at hvordan denne datainnhentingen foregår ikke kvalitetssikres. Ulike studenter vil gjøre dette på ulike måter via allmøter, via e-post eller lignende. Dersom studentene i referansegruppen selv har sterke meninger vil både møtene og referansegrupperapportene kunne være preget av dette. Det var derfor viktig å også gjennomføre en spørreundersøkelse som ble sendt til alle studentene hvor de ble bedt om å oppgi de mest beskrivende tanker og følelser de hadde gjennom semesteret (Tabell 1). Valg av svaralternativer ble gjort med bakgrunn i emneevalueringer før og etter omlegging, samtale med faglærere som hadde vært involvert i emnet samt de fem sentrale faktorene nevnt av Williams og Williams (2011). Svaralternativene ble presentert i randomisert rekkefølge for å unngå overhyppighet i avkrysning på de første alternativene (Gastón Ares \& Jaeger, 2013). Det er mulig å anta at studentene i løpet av semesteret var innom de fleste tanker og følelser som er listet opp i tabell 1. Ideelt i en læringssituasjon er studenten i flytsonen og opplever at det er samsvar mellom læringsaktivitetenes vanskelighetsgrad og egen kompetanse (Pettersen, 2005), men det er naturlig at i enkelte perioder vil studentene vært utenfor flytsonen og det vil påvirke følelsesregisteret. Vi ønsket å få innsikt i hvilke tanker og følelser studentene fant mest beskrivende når de $\mathrm{i}$ ettertid så tilbake på undervisningsopplegget og satte derfor en begrensning på antall alternativer hver student kunne krysse av på.

De akademiske prestasjonene ble signifikant forbedret etter omlegging. Dette er i samsvar med en omfattende metaanalyse av Freeman m.fl. (2014) som fant at undervisning basert på aktive læringsformer forbedret akademiske prestasjoner hos bachelorstudenter sammenlignet med tradisjonelle forelesninger. Resultatene fra undersøkelsene i denne studien må imidlertid tolkes med varsomhet. Analysen er kvasi-eksperimentell, det kan være forskjeller i akademiske prestasjoner mellom studentkull. For å sannsynliggjøre at de forbedrede akademiske prestasjonene faktisk skyltes endret undervisningsopplegg valgte vi å sammenligne med akademisk prestasjon de samme studentgruppene hadde i mikrobiologi. Grunnen til at dette emnet ble valgt er at begge emnene er obligatorisk for studentene og de har emnene samme år, eksempelvis kull 2014 hadde mikrobiologi og produktutvikling i 2014. Likevel ser vi at antallet studenter som har tatt mikrobiologi er høyere enn tallet for produktutvikling. Dette kan skyldes at strykprosenten er høyere i mikrobiologi enn i produktutvikling og det derfor er flere gjentak. Videre er det vanskelig å sammenligne karakterene oppnådd i det 
Nordic Journal of STEM Education, Vol. 1, No. 1 (2017), pp 319-327.

tradisjonelle kontra det studentaktive emnet siden vurderingsformen er endret. Karakterene til studentene før omleggingen var basert på to delvurderinger; en semesteroppgave i gruppe og en individuell skriftlig eksamen. Etter omleggingen er karakterene kun basert på semesteroppgaven som gruppen leverer sammen.

\section{TAKK}

Vi ønsker å takke studenter og ansatte ved Institutt for bioteknologi og matvitenskap ved NTNU for aktiv deltagelse i prosjektet. Takk også til Stimulus - Fondet for Modernisering av Undervisning og Læring i Ingeniørutdanningen ved Avdeling for Teknologi, Høgskolen i Sør- Trøndelag for støtte til å gjennomføre prosjektet.

\section{REFERANSER}

Ares, G., \& Jaeger, S. R. (2013). Check-all-that-apply questions: Influence of attribute order on sensory product characterization. Food Quality and Preference, 28(1), 141-153.

Biggs, J. and Tang, C. (2007). Teaching for Quality Learning at University, 3. ed. Open University Press, ISBN-10 0335221262.

Cazan, A. (2013). Teaching Self Regulated Learning Strategies for Psychology Students. Procedia Social and Behavioral Sciences, Vol. 78, pp.743-747 DOI: 10.1016/j.sbspro.2013.04.387

Chickering, A.W. and Gamson, Z.F. (1987). Seven principles for good practice in undergraduate education. American Association of Higher Education Bulletin, Vol. 39 No. 7, pp. 3-7.

Emnerapport i produktutvikling (2014), Avdeling for teknologi, Høgskolen i Sør-Trøndelag (internt dokument)

Fraser, J.M., Timan, A. L., Miller, K.; Dowd, J.E.; Tucker, L.,Mazur, E. (2014). Teaching and physics education research: bridging the gap. Reports on Progress in Physics, Vol. 77 No. 3, 032401 doi:10.1088/0034-4885/77/3/032401.

Freeman, S., Eddya, L.S., McDonough, M., Smith, M.K., Okoroafor, N., Jordt, H., Wenderoth, M.P. (2014). Active learning increases student performance in science, engineering, and mathematics. $P N A S$, Vol. 111, No. 23, pp. 8410-8415. DOI: 10.1073/pnas.1319030111.

Hamberg, S., Bakken, P., Damen, M.L. (2016). Tilbakemelding og veiledning i høyere utdanning. Hva forklarer studentenes misnøye? NOKUT. [Tilgjengelig fra http://www.nokut.no/Documents/NOKUT/Artikkelbibliotek/Kunnskapsbasen/Notater/2016/Hambe rg__Bakken_Damen_Tilbakemelding_og_veiledning_i_h\%C3\%B8yere_utdanning_2016.pdf]

Hattie, J. and Timperley, H. (2007). The Power of feedback. Review of Educational Research. Vol. 77 No. 1, pp. 81-112 DOI: 10.3102/003465430298487

Haugan, J. og Lysebo, M. (2015). Medstudentvurdering i matematikk og fysikk. Uniped Vol. 38, No. 4, pp. 327-335.

Karlsen, H., Mehli, L., Wahl, E., Staberg, R.L. (2015). Teaching outbreak investigation to undergraduate food technologists. British Food Journal Vol.117, No. 2, pp. 766-778. DOI: http://dx.doi.org/10.1108/BFJ-02-2014-0062

Meyners, M., \& Castura, J. C. (2014). Check-All-That-Apply Questions. In P. Varela \& G. Ares (Eds.), Novel techniques in sensory characterization and consumer profiling: CRC Press

Michelsen, S. og Aamodt, P.O. (2007). Evaluering av Kvalitetsreformen. Sluttrapport. Norges Forskningsråd.

NTNU (u.å.) Referansegrupper. [Tilgjengelig fra http://www.ntnu.no/hf/referansegruppe]

Palmer, D. (2007). What is the best way to motivate students in science? Teaching Science - The Journal of the Australien Science Teachers Association, 53(1), p 38-42. http://hdl.handle.net/1959.13/926804

Pettersen, R.C. (2005). Kvalitetslæring i høgere utdanning. Innføring i problem- og praksisbasert didaktikk. Universitetsforlaget. ISBN 82-15-00557-8

St.meld. nr. 27 (2000-2001). Gjør din plikt - Krev din rett. Kvalitetsreform av høyere utdanning. Kirke, utdannings- og forskningsdepartementet.

Shulman, L.S. (2002). Making differences. A table of Learning. Change: The Magazine of Higher Learning, Vol. 34, No. 6, pp. 36-44. DOI: http://dx.doi.org/10.1080/00091380209605567 
Nordic Journal of STEM Education, Vol. 1, No. 1 (2017), pp 319-327.

Strømsø, H., Lycke, K.H. og Lavås, P. (2006). Når læring er det viktigste. Undervisning i høyere utdanning. Cappelen Akademiske Forlag. ISBN 978-82-02-24988-5

Walpole, R.E. (2016) Probability \& statistics for engineers and scientists. Pearson Education. ISBN 978-1-292-161365;ISBN 1-292-16136

Williams, K., and Williams, C. (2011). Five key ingredients for improving motivation. Research in Higher Education Journal, 11. http://aabri.com/manuscripts/11834.pdf

Zimmerman, B.J. (2002). Becoming a Self-Regulated Learner: An Overview. Theory Into Practice, Vol. 41, No. 2, pp. 64-70 DOI: 10.1207/s15430421tip4102_2 